\title{
Study and Practice of Website-based Collaborated Self-directed Language Learning and Teaching
}

\author{
Li Zhaoxia ${ }^{1}$,Jing Zhihua ${ }^{2}$ \\ Jiaoyu Rd. 178\#, Wenchang, Hainan, the P.R.C. \\ lizhaoxia6688@163.com;279976033@qq.com
}

Keywords: website, collaborate, self-directed, language learning and teaching

\begin{abstract}
Based on the theory of collaborated self-directed study and the strengths of modern education technology, the study explores application of websites for collaborated self-directed college English learning. It introduces the characteristics and functions of the website developed to assist college English teaching in China. It also points out the problems currently existing among teachers and students, and puts forward some suggestions and strategies for the improvement of the application of the website.
\end{abstract}

\section{Introduction}

A new pattern for English teaching was put forward in "The basic requirements for college English teaching" issued by the Department of Education of China (later referred to Basic Requirements), which is called "blended teaching" assisted with modern technology. The requirements advocate teachers to make full use of multimedia technology, especially websites to teach and guide students to do self-directed study. It requires that the technology of multi-media and websites be applied in English teaching. The new teaching method should take the place of the old traditional teacher-focused method. Teaching should be supported by modern information technology, especially network technology to make the English teaching free of the limit of time and places. Teachers should focus more on developing students' ability in self study or individual study rather than on stuffing them with the language itself in the most traditional way. (Basic Requirements, 6) Guided by these principles, the author has developed a website and explored the application of the network-based college English teaching in the past few years, trying to find a proper pattern of English teaching so as to meet the requirements of the new curriculum.

\section{Literature Review}

The pattern of computer assisted language teaching and learning which was started in the late 1990s has been changed from the standalone courseware to varieties of multimedia network, such as using websites to assist language teaching. This new form of network-based language teaching has attracted more and more educators' attention.

Multimedia assisted teaching provides students with more chances and choices in their language study than any other media. Through careful design and development, the courseware used to assist teaching has the characteristics of abundant information, highly integrated media, varieties of special effects and it is easily obtained and used in teaching and learning. It has many advantages over the traditional language teaching approaches. It provides an ideal atmosphere and environment for students to learn the language themselves. Learners can get the information in a very flexible way and individual way, such as choosing what to read, how long to study, how many times to read or practice, etc. By working on the network courseware, students can develop their own ways of study. It can also develop students' ability in self-study and self-management. Their responsibility and motivation can be enhanced. It is especially fit for teaching students at different levels. (Warschauer, 2006:96)

The self-directed study in learning a foreign language is not a new concept. It was put forward in the 1980s. Holec first applied this theory into foreign language teaching. Afterwards other linguistics, such as Dickenson and Little Wood all gave different definitions to self-directed study. The Chinese scholar Mr. Su Dingfang made the following definitions to it after he studied the 
foreign theories:

1) Attitude: Learners adopt an active and eager-to-learn attitude to their study, which means they are responsible for their study and put an effort in their study;

2) Ability: Learners should develop their ability of self-study, self-management and their own study strategies so that they can finish their study separately to their own needs.

3) Environment: Learners should be given enough chances to be exposed to the real or stimulated environment to practice using the language and develop their abilities in real communications. (Su Dingfang, 2004:34)

Network-based study is just to meet the need stipulated by the definitions. It can provide students with an environment for self-directed study. It takes the place of the traditional teacher-focused teaching method and makes it possible for students to study through active practice in learning a foreign language.

\section{The Application of Website-based Teaching}

In order to use the website to assist teaching, the priority is to set up a website which is proper for students to study.

\section{A. Development of the Website}

Our website was designed and developed based on the requirements for the development of students' English ability and the purpose of using the website as a after-class base for students' English study, aiming at making it assist English teaching and learning in an efficient and effective way. We want to make it fit and useful to different kinds of students at different English levels and to meet different needs in learning the language. By visiting the website, students' enthusiasm and motivation in learning the language can be enhanced. Students may be immersed in the stimulated English environment and learn authentic English.

The website is attached to the main website of our college. The website is composed of the following sections: Software Study, Online Communication, English Forum, Bulletin Board, Related Connections and Entertainments, etc. All these sections were programmed through the software of ASP. The data bank is ACCESS, whose functions are powerful and easily accessible.

All the courseware is tailed to the students' need for study at different levels. Some of them were developed by ourselves, while most of software were bought either from abroad or at home.

There is a bank of exercises or tests for both English and non-English major students on the website. We developed a platform for the bank and entered lots of questions for different levels and different types of students. Both the teachers and students can come up exercises based on their own needs and purposes either for teaching or for practicing. There are answers to all the questions. Students may do the problems and get feedback immediately after they are done with the exercises. About the objective problems, students can get the results of the practice at once, knowing which part they do well, which part they need to improve. About the subjective exercises, such as translating or writing exercises, we attach the translated version or the model version for their reference. We also give comments on them so that students may know clearly about the feedback.

The students have to insert their users' names and passwords before they visit the website and study on it. By doing this, the computer automatically keep the record of their time of study on line so that the teachers may know whether they study or not before or after class and how often or how long they study on line. The teacher may give students' grades for regular study partly based on their on-line study performances. They may also know how well the students study and they give them individual help or guidance respectively.

The section for students to study on the website is made up of three parts, which are students' registering system, logging-in system and CAI software Study system. The registering system is designed to insert students' information and keep it in the data bank of ACCESS on the programmer's platform. The logging-in system is designed to verify the codes about the users, such as users' names, passwords, real names, sex, classes, time span to study on line each time, etc. All the information is kept in each teacher's section. Teachers may check and supervise students' study on the website. The software, whether network courseware or power points are provided by teachers 
and sent to the services. Any teacher or student may visit them and use them at any time on the platform.

Besides the above self-study sections, there are on-line communication section and English forum section. The former is of the characteristic of a chatting room with a sound system. In this system, teachers may give on-line lessons, communicate with students, answer their questions or give guidance for their self study.

The section for English forum has more functions. Both teachers and students can send messages, discussing the stuff they learn, the method they use, the problems they meet with and the solutions to them, etc. They can also exchange materials and opinions related to their studies. The number of the users who are working on line and the rosters of the registered users appear on the webpage at the same time, thus students' self study records are kept on the website automatically.

The hard equipment of the website is the server of IBM netfinity 5000, including a Gigabyte network card SCSI hard drive, and other equipment needed to get access to the website of the university. All these are provided by the network center of the university. Besides, streaming media equipment is installed so as to make it possible for videos to be played on the website, too.

\section{B. Application of the Website-based Collaborated Self-directed Teaching Approach}

We have been practicing the pattern of applying the website to assist our teaching at different levels after the website and the courseware were developed and put into use. First of all we divide students into different groups according to their English level through an exam shortly after they came to college and registered them differently. We arrange teachers to be in charge of the teaching and supervision of their self-directed study. In teaching practice, we combine classroom teaching with students' self-directed study on line. Besides attaching the software we develop on our own in classroom teaching, we also provide students lots of other network-based courseware we bought or downloaded for them to study and refer to. We require students to preview their lessons, to study the language points and do some related exercises before class or after class, while in class, the teachers design a lot of activities to check their prevision and self study work. Teachers also supervise their on-line study according to the records kept on the website automatically and give students some advice or guidance to the feedback. Teachers also give grades to self-directed study which account for a large percentage of their final scores. Within the limited class time, teachers focus on those contents which students may feel confused about. Then they create different kinds of activities or projects for students to communicate in the language they learn to improve their skills in listening, speaking, reading, writing and translating. In these activities, such as oral presentation about a topic, conversations, debates, or speeches, students are warmly involved and performed much better since they have self studied the texts and well prepared for them. Thus their abilities in using the language have been improved to a large extent. Meanwhile, teachers also answer the questions students meet with in their self-study in person and give them detailed explanations. By asking students to preview and study before or after class by themselves on line, teachers may have more time to guide students, give them more individual help so that each student can get what help they want from the teacher. Teachers and students discuss the methods in self-directed study and experience together so that most of the students know how to use the website to study. Network-based teaching can provide students with a simulated classroom or environment, in which students may learn a foreign language much better than in a normal classroom with chalk and blackboard. Teachers can give students classes at different places at the same time, students can study in different places and at different time. This makes it possible for teachers to teachers, teachers to students, or students to students to communicate with each other. In order to solve students' problems in time, teachers take turns to be on duty in the computer center in the university to answer questions and participate students' discussion at regular time. Thus students' language skills have been improved greatly because of the application of the website. Students' limited classroom time for English study has been expanded in many ways and to different length.

\section{Existing Problems and Strategies for Improvement}


Network-based teaching has its own advantages over any other teaching approach. However, in our application of website-assisted teaching, we have found some problems.

\section{A. Teachers' Lack of Awareness of Website-based Teaching}

Though website-based teaching has become a major concern for many college teachers, a large proportion of teachers still stick to the most traditional teaching method---with one blackboard and a piece of chalk in class. Both theories and practice of multimedia assisted language teaching should be emphasized to them. Especially they should be exposed to network-based teaching theories, network courseware, on-line teaching equipment and application so that they may have a knowledge of modern technology and its application and know how to use it. (Chen Jianlin, 2004, 30)

\section{B. Students' Lack of Self-control in On-line Study}

Students should develop a good attitude to self-directed study, however a large part of students spend much time in chatting and on-line games. In order to solve the problem, teachers need to be dedicated to guiding and supervising them. Just as Lei Peihua (2004) said, "Teachers should let students aware that successful learners are usually those who are good at managing their own time and efforts in study. They not only know the techniques and strategies of study, have the ability in undertaking different kinds of study activities effectively but also deal with the difficulties and problems they meet with in their study properly.”(Lei Peihua, 2004)

\section{Lack of On-line Study Resources}

Website-based teaching needs adequate varieties of software. Though we have done our best to develop them and buy them, our ability in doing this is very limited. It needs much time and great efforts to develop good courseware.

However, with the development of economy and administrators' focus and emphasis on multimedia assisted teaching, we are sure we can solve the problem and improve our new approach of language teaching.

\section{Acknowledgement}

This paper is sponsored by the project of "Study and Practice of English Autonomous Learning System Based on the Development of Vocational Skills” issued by the Education Bureau of Hainan Province. The project number: Hjsk2012-95

\section{References}

[1] J. Chen, Theory of Network-based College English Teaching and Analysis of Its Application. Foreign Language Visual Education, 2004(6).

[2] P. Gu, Internet and Foreign Language Teaching, Foreign Language Visual Education [J].2004(6).

[3] P. Lei, On Self-directed Teaching Mode in College, Journal of Harbin College, 2004(3).

[4] J. Mo, Study on the Development of Teaching Resources for Self-directed Foreign Language Study at College, Foreign Language Visual Education, 2005(2).

[5] D. Su, Foreign Language Teaching Renovation: Problems and Strategies, Shanghai: Shanghai Foreign Language Press, 2004, pp.31-35.

[6] M. Warschauer, and R. Kern, Network-based Language Teaching: Concepts and Practice, Cambridge: Cambridge University Press, 2006, pp. 48-56. 